\title{
Is high Dose Intravenous Vitamin C Safe to Use in SARS- CoV-2 Treatment?
}

\section{SARS-CoV-2 Tedavisinde Yüksek Doz İntravenöz C Vitamini Kullanımı Güvenli midir?}

(D) Abdurrahim KOÇYİĞİT1,2

1Bezmialem Vakıf University Faculty of Pharmacy, Department of Medical Biochemistry, İstanbul, Turkey

${ }^{2}$ Bezmialem Vakıf University, Traditional and Complementary Medicine Advanced Research and Application Center (GETAMER), İstanbul, Turkey

\begin{abstract}
Severe acute respiratory syndrome coronavirus-2 (SARS-CoV-2) disease which occurred in China in late 2019 and caused pandemia is an important public health problem. The virus has been found to be a member of the beta-coronavirus family of the same species as the SARS-CoV and SARS-related bat CoV's. The way it spreads indicates that SARS-CoV-2 can be transmitted from person to person and be more contagious than SARS-CoV. In general, SARS$\mathrm{CoV}-2$ is an acute disease, but it can be fatal and its mortality is around $2-3 \%$. Acute respiratory distress syndrome (ARDS) is the most important cause of death. Due to cytokines storm, hyperinflammation is a distinctive feature of ARDS, leading to cellular injury, organ failure and death. A fast, accessible, effective and safe treatment is required to save lives and reduce spreading. However, there is still no vaccine or drug developed for the prevention or definitive treatment of SARS-CoV-2. In addition to broad-spectrum antivirals and some other substances for the treatment of the disease, high-dose intravenous (i.v.) vitamin C (VC) is also recommended to take advantage of the antiviral and antioxidant effect. However, it has a pro-oxidant effect rather than an antioxidant. The cumulative effect of oxidative stress caused by inflammation and $\mathrm{VC}$, besides the antiviral effect, can cause serious inflammation and oxidative damage to the tissues. In this review, the function, antiviral efficacy and possible negative consequences of high dose i.v. VC recommended for SARS-CoV2 treatment will be discussed in the light of the literature.
\end{abstract}

Keywords: SARS-CoV-2 treatment, vitamin c, intravenous, prooxidant, antioxidant
ÖZ

2019 sonlarında Çin'de ortaya çıkan şiddetli akut solunum sendromu koronavirüs-2 (SARS-CoV-2) hastalığ 1 , pandemiye neden olan çok önemli bir halk sağlığı sorunudur. Virüsün, SARS-CoV ve SARS ile ilgili, yarasa $\mathrm{CoV}$ ile aynı türlerde, beta-koronavirüs ailesinin bir üyesi olduğu tespit edilmiştir. Bulgular, SARS-CoV-2'nin kişiden kişiye damlacık veya temas yoluyla bulaşabileceğini ve bulaşıcılığının SARSCoV'den daha fazla olduğunu göstermektedir. SARS-CoV-2 akut geçen bir hastalık olmakla birlikte, yaşlılarda ve eşlik eden hipertansiyon gibi kronik hastalığı olanlarda daha ölümcül olabilmekte, mortalite oranı \%2-3 dolayında seyretmektedir. Hastalıkla birlikte görülen akut solunum sıkıntısı sendromu (ARDS) en önemli ölüm nedenidir. Hastalıkta, sitokin fırtınasına bağlı artmış enflamasyon ve oksidatif stres, hücresel hasar ve organ yetmezliği, ölüme yol açan ARDS'nin ayırt edici özelliğidir. Hastalarda hayat kurtarmak için hızlı, erişilebilir, etkili ve güvenli tedavi yöntemlerine ihtiyaç duyulmaktadır. Bununla birlikte, SARS-CoV-2 hastalığının önlenmesi veya kesin tedavisi için geliştirilmiş bir aşı veya ilaç henüz bulunamamıştır. Hastalığın tedavisine yardımcı olabilecek geniş spektrumlu antiviral veya antimalaryal ilaçlar yanında, antiviral veya antioksidan etkisinden yararlanılmak üzere, yüksek doz intravenöz (i.v.) C vitamini (CV) kullanımı da önerilmektedir. Ancak, yüksek doz i.v. CV uygulaması, doza bağımlı olarak antioksidan etkiden ziyade, pro-oksidan etki ile ciddi oksidatif stres artışına neden olabilmektedir. Hastalarda görülen şiddetli enflamasyon ve yüksek doz CV'nin neden olduğu oksidatif stres, kümülatif olarak, antiviral etki yanında dokularda ciddi enflamasyon artışına oksidatif hasara neden olabilmektedir. $\mathrm{Bu}$ derlemede SARS-CoV-2 tedavisi için önerilen yüksek doz i.v. CV'nin pro-oksidan fonksiyonu, antiviral etkinliği ve doza bağımlı istenmeyen olası sonuçları literatür ışığında tartışılacaktır.

Anahtar Sözcükler: SARS-CoV-2 tedavisi, vitamin C, intravenöz, prooksidan, antioksidan
Address for Correspondence: Abdurrahim KOÇYičiT, Bezmialem Vakıf University Faculty of Pharmacy, Department of Medical Biochemistry, İstanbul, Turkey, Bezmialem Vakıf University, Traditional and Complementary Medicine Advanced Research and Application Center (GETAMER), ìstanbul, Turkey E-mail: abdurrahimkocyigit@yahoo.com ORCID ID: orcid.org/0000-0003-2335-412X
Received: 02.05.2020

Accepted: 11.06 .2020

Cite this article as: Koçyiğit A. Is high Dose Intravenous Vitamin C Safe to Use in SARS-CoV-2 Treatment?. Bezmialem Science 2020;8(Supplement 3):126-30. 


\section{Introduction}

Coronaviruses (CoV) are single-chain, positive polarity, enveloped RNA viruses that cause a variety of diseases, from the common cold to more serious diseases such as the Middle East respiratory syndrome-CoV (MERS-CoV) and severe acute respiratory syndrome $\mathrm{CoV}$ (SARS-CoV) (1). The virus, which first appeared in the city of Wuhan in Hubei province of China in 2019 and spread all over the World and caused a pandemia, is in the sub-genus of the Sarbecovirus, a beta-CoV type including SARS-CoV and MERS-CoV, and has been named as SARSCoV-2 by the World Health Organization (2). The mechanism of infection is the binding of the virus to the membrane-bound form of angiotensin converting enzyme-2 (ACE-2) and the proliferation of the complex by being taken into the cell by the host cell (3). The time from exposure to SARS-CoV-2 to the onset of symptoms (incubation time) is 2 to 14 days on average. SARS-CoV-2 infection causes severe acute respiratory disease with fever, cough and shortness of breath in many confirmed people. The organ in which SARS-CoV-2 is most effective is the lung, and the virus goes to the lungs through the respiratory tract, binds to ACE-2 receptors on the cell surfaces of the alveoli in the lung, enters the cell and multiplies inside the cell, and causes cell damage and serious inflammation. Acute inflammation caused by the virus can lead to acute respiratory distress syndrome (ARDS), which can be fatal (3). The disease is accompanied by neutrophil infiltration in the lungs, immune suppression, severe hypoxemia, and hyperferritinemia due to cytokine storm (4). Rapid production of free oxygen species (ROS) with the mechanism induced by inflammation and known as respiratory burst is the main characteristic of ARDS, which causes significant oxidative stress, cell damage, organ failure and death (5). The virus is more mortal in the elderly and those with chronic diseases such as hypertension, cardiovascular diseases and diabetes, and the mortality rate is around 2-3\% (6).

Currently, a drug specific to SARS-CoV-2 has not been developed. Because viruses use normal cellular metabolic pathways as opposed to bacteria and fungi to reproduce, it is very difficult to design a drug that shows antiviral activity without damaging the cells (7). Therefore, as with other viruses, besides broad-spectrum antiviral drugs, the disease is tried to be treated with symptomatic supportive therapies. One of the supportive treatments is the use of high-dose intravenous (i.v.) vitamin C (CV).

Normally, CV is a powerful antioxidant vitamin capable of delivering electrons and cleaning ROS (8). Besides that, they show a pro-oxidant effect in the presence of pharmacologically high doses of transition metals such as iron and copper (9). In fact, it has been shown in many studies that high-dose CV causes a damage in DNAs of cancer cells and their death with pro-oxidant effect, so that it can be used as an anti-cancer drug (10). In antiviral treatment, it was desired to benefit from both antioxidant and pro-oxidant effects of high-dose CVs. While some researchers suggest the use of high dose i.v. CV to kill the virus with pro-oxidant effect, some recommends the use of high-dose i.v. $\mathrm{CV}$ as an antioxidant for the prevention of damage due to the increased ROS production caused by infection and inflammation (13-15).

In short, in the treatment of the disease, both as a pro-oxidant to kill the virus and as an antioxidant to eliminate oxidative damage, pharmacological i.v. high dose $\mathrm{CV}$ is recommended. However, in case of the use of high dose i.v. CV, cumulative effect of increased oxidative stress caused by inflammation due to disease and increased ROS with pro-oxidant effect rather than antioxidant effect, depending on the dose, may cause serious inflammation and oxidative damage in the organism besides antiviral effect. In the light of the literature, this review will discuss the structure of the $\mathrm{CV}$, its physiological functions, and the use of pharmacologically high doses of CV in SARS-CoV-2 treatment and possible pathological results.

\section{Results}

\section{Biochemical and Molecular Features of Vitamin C}

$\mathrm{CV}$, also known as ascorbic acid, is a monosaccharide derivative and has a structure similar to glucose and other six-carbon monosaccharides. Although it can be synthesized in most organisms, L-gulono-g-lactone oxidase, which catalyzes the last step of L-ascorbic acid biosynthesis, is a very important vitamin that cannot be synthesized in humans due to lack of enzyme (16). When CV is taken orally, plasma and tissue concentrations are tightly controlled by at least 4 mechanisms, namely absorption, tissue accumulation, renal excretion and re-absorption in healthy people. When taken orally, absorption is reduced depending on dose and the achievable maximum plasma CV concentration is about $250 \mathrm{micromol} / \mathrm{L}$ (um/L). On the contrary, when ascorbic acid is injected i.v. or when given by i.v. infusion, pharmacological $\mathrm{CV}$ concentrations can be increased to $25-30 \mathrm{mmol} / \mathrm{L}$ levels (100 fold) (17).

\section{Physiopathological Features of SARS-CoV-2 Disease}

Evidence obtained to date about SARS-CoV-2 disease has shown that hyperinflammation due to cytokine storm syndrome is very common in patients with severe clinical course and ARDS is the most important cause of mortality (4). When the virus infects lung cells, as a result of activation of epithelial cells and alveolar macrophages in the airway against the virus, chemotactic chemokines such as macrophage inflammatory protein 2 (MIP2 ), monocyte chemoattractant protein-1 (MCP-1), tumor necrosis factor alpha (TNF- $\alpha$ ), interleukin-6 (IL-6), interferon gamma (IFN- $\gamma$ ), and interleukin- 8 (IL-8) are released (18).

As an early response to inflammation, they can cause an abnormal permanent cascade known as cytokine storm as a result of the entry of macrophage cells into the lung and excessive release of inflammatory cytokines (19). Inflammatory mediators involving the release of chemokines, ROS, and coagulation factors, along with cytokine storm, are associated with continuously stimulated signal transduction (20). NADPH oxidase (NOX) is an important enzyme that is a source of superoxide/ROS in the pathogenesis of viral infection and initiates respiratory burst, and the target is to eliminate the pathogen (21). Hydrogen peroxide $\left(\mathrm{H}_{2} \mathrm{O}_{2}\right)$, which 
is a cytotoxic molecule in the catalyzer of superoxide dismutase (SOD), is synthesized from superoxide radical $\left(\mathrm{O}_{2}^{-*}\right)$ formed as a result of the reaction.

As a result of $\mathrm{O}_{2}^{-}$reaction with $\mathrm{H}_{2} \mathrm{O}_{2}$ (Haber-Weiss reaction) or $\mathrm{Fe}^{2}+$ reaction with $\mathrm{H}_{2} \mathrm{O}_{2}$ (Fenton reaction, in the catalyzer of myeloperoxidase (MPO) enzyme of Hydroxyl radical (HO), which is the most toxic radical, and chlorine $\left(\mathrm{Cl}^{-}\right)$, hypochlorous acid, which is known as bleacher, is produced (22).

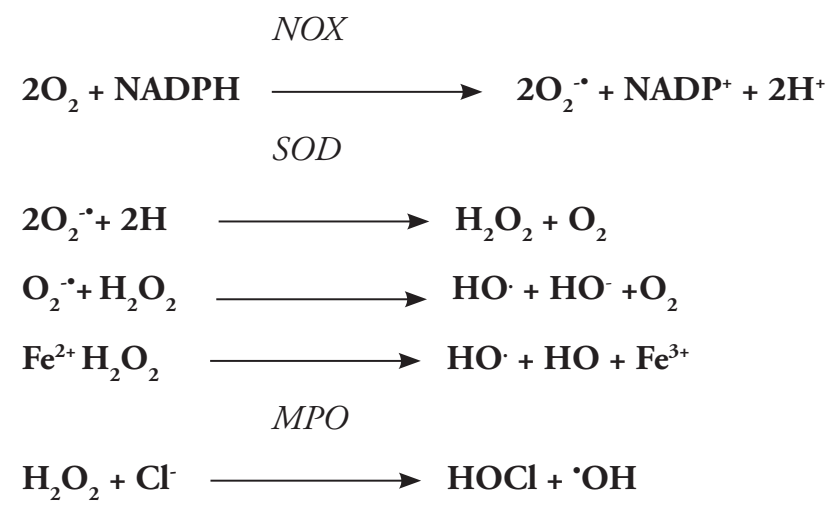

Although the target of ROS produced with respiratory burst stimulated with infection is to kill the microorganism, excessive and long-term ROS increase can cause lung cell damage and various chronic diseases including cancer (23).

One of the most important laboratory findings of SARS-CoV-2 infection is the excessive increase in serum ferritin levels with cytokine storm. Serum ferritin levels, normally below $200 \mathrm{ng} /$ $\mathrm{mL}$, may increase from $500 \mathrm{ng} / \mathrm{mL}$ to thousands $(24,25)$.

\section{Use of Vitamin C in the Treatment of SARS-CoV-2 Disease}

Although no definitive medication has been found for the treatment of the disease, one of the symptomatic and supportive treatment approaches is the administration of i.v. $\mathrm{CV}$ at pharmacologic doses increasing from 2-3 gr. to 60-90 gr. There are two different approaches of researchers who advocate the treatment of the disease with $\mathrm{CV}$ in pharmacological doses. The first approach is that i.v. high dose $\mathrm{CV}$ causes ROS production with pro-oxidant effect in the presence of transition metals such as free iron and copper, and high ROS levels show antiviral effects by creating oxidative damage in virus genome, proteins and lipid structures. As a matter of fact, studies showing the antiviral activity of high-dose CV for different viruses have been reported (26,27). In an in vitro study Cheng et al. (28) showed that pharmacological doses of CV increase the ROS production in extracellular fluid and kill not only isolated influenza viruses but also viruses within normal human bronchial epithelial cells. Jariwalla and Harakeh (27) reported that high doses of i.v. CV (at milimolar levels) should be used in treatment as it may have an anti-viral effect on SARS-COV-2with pro-oxidant effect and. The second approach is to take advantage of the antioxidant effect of high-dose $\mathrm{CV}$ to prevent oxidative damage resulting from hyperinflammation in patients. Of the researchers advocating this approach, Cheng et al. (13) reported that pharmacological doses of CV, which is a powerful antioxidant, should be used to prevent oxidative damage caused by ROS produced as a result of hyperinflammation developing in association with cytokine storm in SARS-CoV-2 disease. Boretti et al. (15) suggested that the use of i.v. CV in the treatment of SARS-CoV-2 may be effective in stopping cytokine storm.

$\mathrm{CV}$ at physiological levels is also involved in the regeneration of fat-soluble vitamin $\mathrm{E}$, as a powerful water-soluble antioxidant that has the potential to purify ROS and reactive nitrogen species (RNS) in biological fluids by giving two electrons with direct effect (29).

In addition to its strong antioxidant feature, $\mathrm{CV}$ has a coenzyme property for many enzymes in the groups of monooxygenases, dioxygenases and hydroxylases in the synthesis of collagen, carnitine and proteoglycans (30). It is also known that CV contributes to immune defense by supporting various cellular functions of both natural and adaptive immune system (31). However, high doses of $\mathrm{CV}$ show the pro-oxidant effect in the presence of free iron $\left(\mathrm{Fe}^{3+}\right)$ and copper $\left(\mathrm{Cu}^{2+}\right)$, and cause the production of $\mathrm{O}_{2}$ and $\mathrm{OH}$ radicals, which are among the most important ROS components, with the Fenton and Heber-Weiss reactions (32).

Ascorbate $\left(\mathrm{AH}^{-}\right)+\mathrm{Fe}^{3+}$ or $\mathrm{Cu}^{2+} \longrightarrow$ Semidehydroascorbate $\left(\mathrm{A}^{-}\right)+\mathrm{Fe}^{2+}$ or $\mathrm{Cu}^{1+}$

Free $\mathrm{Fe}^{2+}+$ or $\mathrm{Cu}^{1+}$ that occurs causes ROS production by a reaction known as the Fenton reaction.

$$
\begin{aligned}
& \mathrm{Fe}^{2+} \text { or } \mathrm{Cu}^{1+}+\mathrm{H}_{2} \mathrm{O}_{2} \longrightarrow \text { or } \\
& \mathrm{Fe}^{2+} \text { or } \mathrm{Cu}^{3+} \text { or } \mathrm{Cu}^{2+}+\mathrm{OH}_{2} \longrightarrow \mathrm{OH}^{-} \\
& \mathrm{Fe}^{3+} \text { or } \mathrm{Cu}^{2+} \mathrm{O}^{--} \longrightarrow \mathrm{Fe}^{3+} \text { or } \mathrm{Cu}^{2+}+\mathrm{O}_{2} \\
& \hline \mathrm{Fe}^{2+} \text { or } \mathrm{Cu}^{1+}+\mathrm{HO}^{+}+\mathrm{OH}^{-}
\end{aligned}
$$

As a matter of fact, studies on the use of pharmacological doses of $\mathrm{CV}$ as an anti-cancer drug in cancer treatment are being carried out by benefiting from the pro-oxidant feature of $\mathrm{CV}$ at pharmacological doses and a phase I/IIa study on the use of i.v. high-dose CV in pancreas cancer has been reported (33).

Ascorbate can be transported to the cell cytoplasm either through passive glucose transporters GLUT-1,2,3 and 4 in the form of dehydroascorbate or via sodium dependent ascorbate transporters (SVCTs) (34). In particular, as a result of SVCTs mediated transport, $\mathrm{CV}$ concentration in some tissues may be 100 times higher than in the outer of cell (8). It is known that cancer cells consume a lot of glucose (Warburg effect) because it uses glucose as an energy source and generates energy from glucose with anerobic metabolism (35). Because CV is more intense in cancer cells than in other cells since the molecular structure of CV is similar to glucose and uses GLUTs in the entry into cell, it can show more cytotoxic effect in cancer cells with selective pro-oxidant effect $(10,36)$. When a high dose of i.v. CV is administered in SARS-CoV-2 infection, unlike cancer, it does not have a tissue or cell to concentrate on, and because of its 
high ability to release iron from ferritin, which is very high in infection, $\mathrm{CV}$ produces a higher level of ROS with pro-oxidant effect. Indeed, in vitro and in vivo studies have shown that $\mathrm{CV}$ releases iron from ferritin and significantly increases the free iron ratio $(37,38)$. In physiological concentrations, the contribution of $\mathrm{CV}$ to the release of iron from ferritin is quite low, but its pharmacological high doses have been found to have a high contribution to releasing iron from ferritin (39). In addition to the oxidative stress and high ferritin levels caused by cytokine storming in the vast majority of patients with SARS-CoV-2, prooxidant activity caused by high-dose i.v. CV may cause further increase of oxidative stress with cumulative effect and oxidative stress may show antiviral effect by making oxidative damage on virus protein and lipid and especially RNAs. As a matter of fact, RNAs are known to be more prone to oxidative damage than DNA (40).

In addition, high oxidative stress may also cause serious oxidative damage in the patient's protein lipids and DNA as well as antiviral effect. As a matter of fact, studies showing that highdose $\mathrm{CV}$ causes oxidative damage in cells with pro-oxidant effect have been conducted. Duarte et al. (41) showed that the physiological concentration of $100 \mathrm{mikromol} / \mathrm{L}$ (um/L) VC did not cause DNA damage in fibroblast cells, but at a concentration above $100 \mathrm{mikromol} / \mathrm{L}(\mathrm{um} / \mathrm{L}$ ), it caused DNA damage depending on dose. As the cause of the damage, it has been shown that $\mathrm{H}_{2} \mathrm{O}_{2}$, which occurs as a result of autooxidation of $\mathrm{CV}$ outside the cell, enters the cells by passive diffusion and increases ROS production with pro-oxidant activity as a result of reaction with intracellular free iron. With the use of highdose i.v. CV, which is recommended for the treatment of SARSCOV-2, plasma levels of $10-20 \mathrm{mmol} / \mathrm{L}$, which are $100-200$ times higher than the normal level, can be reached (42). ROS which is produced due to inflammation, as well as increased ROS production with pro-oxidant activity, may cause cumulative high oxidative stress formation. It is known that oxidative stress can cause lipid peroxidation (43), protein oxidation (44), cell death with DNA damage, mutations, genomic instability and serious chronic diseases including cancer (45). However, in SARS$\mathrm{COV}-2$ disease, administration of $\mathrm{CV}$ as an antioxidant at a dose that can neutralize high levels of ROS caused by inflammation due to cytokine storm may be beneficial in treatment. However, preclinical and clinical dose optimization studies are required for the appropriate dose.

\section{Conclusion}

Since there is still no specific treatment method with proven reliability and effectiveness for SARS-CoV-2 disease, which affects the whole world, many studies are being conducted to find an effective drug. However, due to the urgency of the current situation and the limited scientific data, some treatment options with limited data on their effectiveness are suggested or used for SARS-CoV-2 disease. One of these treatments is the administration of pharmacological dose of i.v. CV. Although CV is a powerful antioxidant vitamin in physiological doses, it can increase ROS production in pharmacological doses by showing pro-oxidant effect in the presence of metals such as free iron and copper. In addition to ROS in which endogen is produced in association with the stimulation of high levels of inflammation in SARS-CoV-2 disease, ROS produced due to pro-oxidant activity caused by high CV levels together with high ferritin levels may cause cumulatively excessive ROS increase. The resulting ROS may have antiviral effects but may also cause serious oxidative damage in the patient. Therefore, before the use of high dose i.v. $\mathrm{CV}$ as either antiviral or antioxidant in the treatment of SARS$\mathrm{CoV}-2$ disease, pre-clinical and clinical studies should be done to optimize the dose to be applied.

Peer-review: Externally peer reviewed.

Financial Disclosure: The authors declared that this study received no financial support.

\section{References}

1. McIntosh K, Perlman S. Coronaviruses, including severe acute respiratory syndrome (SARS) and Middle East respiratory syndrome (MERS). Mandell, Douglas, and Bennett's Principles and Practice of Infectious Diseases, Updated Edition 8th ed. Philadelphia, PA: Elsevier Saunders; 2015.

2. Lai C-C, Shih T-P, Ko W-C, Tang H-J, Hsueh P-R. Severe acute respiratory syndrome coronavirus 2 (SARS-CoV-2) and corona virus disease-2019 (COVID-19): the epidemic and the challenges. Int J Antimicrob Agents 2020;55:105924.

3. Zhang H, Penninger JM, Li Y, Zhong N, Slutsky AS. Angiotensinconverting enzyme 2 (ACE2) as a SARS-CoV-2 receptor: molecular mechanisms and potential therapeutic target. Intensive Care Med 2020;46:586-90.

4. Mehta P, McAuley DF, Brown M, Sanchez E, Tattersall RS, Manson JJ. COVID-19: consider cytokine storm syndromes and immunosuppression. Lancet 2020;395:1033-4.

5. Hecker L. Mechanisms and consequences of oxidative stress in lung disease: therapeutic implications for an aging populace. Am J Physiol 2018;314:L642-53.

6. Xu Z, Shi L, Wang Y, Zhang J, Huang L, Zhang C, et al. Pathological findings of COVID-19 associated with acute respiratory distress syndrome. Lancet Respir Med 2020;8:420-422.

7. Jasim S, Naji M. A Review Novel Antiviral Agents: A Medicinal Plant Perspective, 2003. http. www blackwell-synergy com/doi/ pdf/101046/j:1365-2672.2003.

8. Du J, Cullen JJ, Buettner GR. Ascorbic acid: chemistry, biology and the treatment of cancer. Biochimic Biophys Acta 2012;1826:443-57.

9. Osiecki M, Ghanavi P, Atkinson K, Nielsen LK, Doran MR. 2010. The ascorbic acid paradox. Biochem Biophys Res Commun 400:466-70.

10. Lee SJ, Jeong J-H, Lee IH, Lee J, Jung JH, Park HY, et al. Effect of high-dose vitamin $\mathrm{C}$ combined with anti-cancer treatment on breast cancer cells. Anticancer Res 2019;39:751-8.

11. Erol A. High-dose intravenous vitamin C treatment for COVID-19. ( Dergi bilgisine ulaşamadım researchgate olabilir, ama emin değilim )2020 Preprint.

12. Pawar AY. Combating devastating COVID-19 by drug repurposing. Int J Antimicrob Agents 2020;56:105984. 
13. Cheng RZ. Can early and high intravenous dose of vitamin $C$ prevent and treat coronavirus disease 2019 (COVID-19)? Med Drug Discov 2020;5:100028.

14. Wang L, Wang Y, Ye D, Liu Q. A review of the 2019 Novel Coronavirus (COVID-19) based on current evidence. Int J Antimicrob Agents 2020;55:105948.

15. Boretti A, Banik BK. Intravenous Vitamin C for reduction of cytokines storm in Acute Respiratory Distress Syndrome. PharmaNutrition 2020:100190.

16. Nishikimi M, Fukuyama R, Minoshima S, Shimizu N, Yagi K. Cloning and chromosomal mapping of the human nonfunctional gene for L-gulono-gamma-lactone oxidase, the enzyme for L-ascorbic acid biosynthesis missing in man. J Biol Chem 1994;269:13685-8.

17. Levine M, Padayatty SJ, Espey MG. Vitamin C: a concentrationfunction approach yields pharmacology and therapeutic discoveries. Adv Nutr 2011;2:78-88.

18. Doherty PC, Turner SJ, Webby RG, Thomas PG. Influenza and the challenge for immunology. Nat Immunol 2006;7:449-55.

19. Perrone LA, Plowden JK, García-Sastre A, Katz JM, Tumpey TM. $\mathrm{H} 5 \mathrm{~N} 1$ and 1918 pandemic influenza virus infection results in early and excessive infiltration of macrophages and neutrophils in the lungs of mice. PLoS Pathog 2008;4:e1000115.

20. Chousterman BG, Swirski FK, Weber GF. Cytokine storm and sepsis disease pathogenesis. New York: Springer; 2017:517-28.

21. Maeda H, Akaike T. Oxygen free radicals as pathogenic molecules in viral diseases. Proc Soc Exp Biol Med 1991;198:721-7.

22. Vlahos R, Selemidis S. NADPH oxidases as novel pharmacologic targets against influenza A virus infection. Mol Pharmacol 2014;86:747-59.

23. Li N, Parrish M, Chan TK, Yin L, Rai P, Yoshiyuki Y, et al. Influenza infection induces host DNA damage and dynamic DNA damage responses during tissue regeneration. Cell Mol Life Sci 2015;72:297388.

24. Zhou F, Yu T, Du R, Fan G, Liu Y, Liu Z, et al. Clinical course and risk factors for mortality of adult inpatients with COVID-19 in Wuhan, China: a retrospective cohort study. Lancet 2020;395:1054-62.

25. Cron RQ, Chatham WW. The rheumatologist's Role in Covid-19. J Rheumatol 2020;47:639-42.

26. Colunga Biancatelli RML, Berrill M, Marik PE. The antiviral properties of vitamin C. Milton Park, UK: Taylor \& Francis; 2020.

27. Jariwalla RJ, Harakeh S. Antiviral and immunomodulatory activities of ascorbic acid. In: Subcellular biochemistry New York: Springer; 1996: 215-31.

28. Cheng LL, Liu YY, Li B, Li SY, Ran PX. 2012. [An in vitro study on the pharmacological ascorbate treatment of influenza virus]. Zhonghua Jie He He Hu Xi Za Zhi 35:520-3.
29. Sharma MK, Buettner GR. Interaction of vitamin C and vitamin $E$ during free radical stress in plasma: an ESR study. Free Radic Biol Med 199314:649-53.

30. LeBlanc JG. Introductory Chapter: Vitamin C. In: Vitamin C-an Update on Current Uses and Functions. London; IntechOpen: 2019.

31. Carr AC, Maggini S. Vitamin C and immune function. Nutrients 2017;9:1211.

32. Boatright WL. Oxygen dependency of one-electron reactions generating ascorbate radicals and hydrogen peroxide from ascorbic acid. Food Chem 2016;196:1361-7.

33. Polireddy K, Dong R, Reed G, Yu J, Chen P, Williamson S, et al. High dose parenteral ascorbate inhibited pancreatic cancer growth and metastasis: mechanisms and a phase I/Ila study. Sci Rep 2017;7:1-15.

34. Harrison FE, May JM. Vitamin C function in the brain: vital role of the ascorbate transporter SVCT2. Free Radic Biol Med 2009;46:71930 .

35. Liberti MV, Locasale JW. The Warburg effect: how does it benefit cancer cells? Trends Biochem Sci 2016;41:211-8.

36. Franqui-Machin R, Xu H, Yethava Y, Frech I, Tricot GJ, Zhan F. Multiple Myeloma Tumor Cells Are Selectively Killed By Pharmacologically-Dosed Ascorbic Acid. Blood 2017;130 (Suppl 1):5391.

37. Bienfait H, Van Den Briel M. Rapid mobilization of ferritin iron by ascorbate in the presence of oxygen. Biochimic Biophysic Acta 1980;631:507-10.

38. Badu-Boateng C, Naftalin RJ. Ascorbate and ferritin interactions: Consequences for iron release in vitro and in vivo and implications for inflammation. Free Radic Biol Med 2019;133:75-87.

39. Badu-Boateng C, Pardalaki S, Wolf C, Lajnef S, Peyrot F, Naftalin RJ. Labile iron potentiates ascorbate-dependent reduction and mobilization of ferritin iron. Free Radic Biol Med 2017;108:94-109.

40. Li Z, Wu J, DeLeo CJ. 2006. RNA damage and surveillance under oxidative stress. IUBMB life 58:581-8.

41. Duarte TL, Almeida GM, Jones GD. Investigation of the role of extracellular $\mathrm{H} 2 \mathrm{O} 2$ and transition metal ions in the genotoxic action of ascorbic acid in cell culture models. Toxicol Lett 2007;170:57-65.

42. Carr AC, Cook J. Intravenous vitamin C for cancer therapyidentifying the current gaps in our knowledge. Front Physiol 2018;9:1182.

43. Gaschler MM, Stockwell BR. 2017. Lipid peroxidation in cell death. Biochem Biophys Res Commun 482:419-25.

44. Møller IM, Rogowska-Wrzesinska A, Rao R. Protein carbonylation and metal-catalyzed protein oxidation in a cellular perspective. J Proteomics 2011:74:2228-42.

45. Kryston TB, Georgiev AB, Pissis P, Georgakilas AG. Role of oxidative stress and DNA damage in human carcinogenesis. Mutat Res Mutagenesis 2011;711:193-201. 